\title{
On the influence of foreign players on the success of football ${ }^{1}$ clubs
}

\author{
Vicente Royuela \\ Department of Econometrics and Statistics, University of Barcelona. \\ Avda Diagonal 690. 08034 Barcelona (Spain) Fax +34 934021821 \\ vroyuela@ub.edu \\ Roberto Gásquez \\ Department of International Economics, University of Barcelona \\ Avda Diagonal 690. 08034 Barcelona (Spain) \\ gasquez@ub.edu
}

\begin{abstract}
This paper analyzes whether having more foreign players may influence the performance of football teams. We do so by comparing a cross section of close to one thousand football clubs all over the world. We find that, on average, those teams in leagues with more foreign players display better results in the World classification. Nevertheless, within every league, where all teams have the same regulations, having more foreign players has no effect. In the end, when all teams have the same possibilities for importing better players from abroad, what matters is the financial power to choose the better ones.
\end{abstract}

JEL codes: C33, C53, L83

Key words: Elo rating, football success, FIFA ranking, international migration

\section{Acknowledgements}

V. Royuela thanks the support of ECO2016-75805-R.

\footnotetext{
${ }^{1}$ That is soccer in North America.
} 


\section{INTRODUCTION}

Football is the most globalized sport in the world ${ }^{2}$, and it is an important part of the global economy ${ }^{3}$. The importance of football is such that it can even be used as an indicator of social development (Gásquez and Royuela, 2014).

Nowadays international migration is a very important phenomenon, and football is not alien to this reality. Football clubs try to hire the best players, no matter where they come from, while football players aim to join the best clubs to enjoy better salaries and professional prospects. In a globalized sport such as football, talent can be anywhere and what results is an international dimension, probably larger than in any other profession.

This article analyzes the impact of such migration flows on performance, i.e. if having a larger proportion of foreign football players significantly influences the success of football clubs. Most papers analyzing the impact of foreign football players are addressed at the national team level. Our contribution expands current knowledge by considering a comprehensive data set of international clubs all over the world that allows for conducting both national comparisons and a detailed analysis at the club level.

Our results confirm that having more foreign football players favors the performance of clubs at the international level, although such influence vanishes within each individual national league, where every club faces the same level of restrictions in hiring foreign talent. Having more foreign players only has a positive effect for clubs in football confederations where a learning process can ultimately benefit home clubs. On the other hand, in better-ranked leagues we do not observe any benefit once we account for local football norms, as all clubs have the same possibilities for hiring better players which makes it, in the end, a financial issue.

Next, section II reviews several facts and the existing literature on the topic. Section III introduces the theoretical-analytical framework used in this research. Section IV presents the data sources. Section V sets out the empirical model and presents the estimation results, several additions to the model and a sensitivity analysis and robustness checks. Finally, section VI offers some conclusions.

\section{LITERATURE REVIEW AND STYLISED FACTS}

Several works have studied the phenomenon of migration in football. Specifically, they have focused on analyzing the effect of footballer migration on the performance of national teams.

\footnotetext{
${ }^{2}$ According to FIFA, 2014 Brazil's World Cup reached 3.2 billion people, and one billion watched the final.

${ }^{3}$ Dimitrov et al. (2006), cited by the European Commission's White Paper on Sport, estimates that the sports industry in the European Union accounts for a global impact of 3.7 percent of total GDP and 5.4 percent of total employment.
} 
A few recent studies (Baur and Lehman, 2007; Gelage and Dobson, 2007; Berlinschi et al., 2013; Yakamura, 2009; Allan and Moffat, 2014) have investigated the benefits of having national association football players playing in clubs outside their domestic league. Competing in higher quality leagues allows them access to better training and tactical methods, and players who play abroad improve the performance of the national team. As opposed to these authors and contrary to conventional economical wisdom, Frick (2009) finds that the migration of players to the financially rewarding leagues in Western Europe does not improve national team performance.

Baur and Lehman (2007) examine the effect of having a large proportion of foreign players on the performance of the national team. Contrary to public opinion, they defend that having more foreigners in your league may result in the sporting success of your national team. These authors conclude that imports in a football league improve the performance of the national team, because players benefit from knowledge-spillovers. Imported players have some skills or qualities from which other players can learn and benefit. They suggest as a future research agenda extending the study of the effect of imported players on football clubs, research that, to our knowledge, had not been addressed yet.

Along the same lines, Alvarez et al. (2011) look at whether there is an impact on the performance of a national basketball team from having non-domestic players within the national leagues. When skilled labor is imported, skill levels of local workers may be raised by contact with new techniques and practices. With the study of European basketball, the authors demonstrate that an increase in the number of foreigners in a domestic league tends to generate an improvement in the performance of the national team.

Migration and labor mobility, is the human side of the agglomeration story. Consequently, we can see the positive effects of these flows in terms of the three sources of agglomeration economies reported by Duranton and Puga (2004). Among them, one can expect that the matching effect dominates: stronger and more successful clubs, usually with higher financial resources, are the ones expected to hire the best players, regardless of their origin. Still, as reported in many of the papers studying the impact on national teams' performance, the learning effect can be substantial, through knowledgespillovers, which can take place both at club level and at national level. Finally, sharing common legal and administrative frameworks within a national league or international environment (such as UEFA's Champions League) can help to exploit fully the market potential of foreign players, by having a larger global audience worldwide or by improving a club’s merchandising sales.

Agglomeration economies also have several other consequences, for example distributional (Behrens and Robert-Nicoud, 2014). On this theme, Milanovic (2005) focuses on the impact of football players' international migration on inequality between clubs. He develops a theoretical model predicting that opening of football markets reduces inequality between national teams due to skills spillover between players. Binder and 
Findlay (2012) study the effects on competitive balance of the Bosman Ruling on National and Club Football in Europe. ${ }^{4}$ According to their results, the competitive balance in domestic leagues has not decreased over time. That is, imported players have gone to a variety of clubs, not just the top clubs. In another area of research, Kleven et al. (2013) analyze the effects of tax on international migration. The authors found evidence that football migration is conditioned by taxes.

In fact, legal barriers and conditionings for migration are one of the key aspects to be considered. According to data from the Football Observatory, since the Bosman ruling the percentage of foreign players recruited by clubs in the "Big Five" European football leagues ${ }^{5}$ increased from around $19 \%$ in the 1995/1996, to around $46 \%$ in the $2014 / 2015$. In recent years we see that some clubs have come to have more than $90 \%$ international migrant players (e.g. Swansea F.C. in the Premier League).

This reality has turned into a debate in the media. Attitudes towards migration of footballers raise several issues related to the political economy of high-level sport, but also raise broader questions about national identity, citizenship, freedom of work and the inclusion or exclusion of foreigners in local labor markets (Taylor, 2006).

Both UEFA and FIFA have tried to, and in fact have partially been able to, limit the number of foreigners in order to preserve the national identity of clubs. Critics argue that excessive mobility threatens the configuration of local identities and worsens national football team performance: former FIFA president, Sepp Blatter, defended that having more foreigners is neither good for the development of football, nor for the education of young players, and supported FIFA in opening the door to foreign players but not so much that this identity is lost. Other examples of this attitude can be found in the words of the former Italian prime minister and AC Milan president, Silvio Berlusconi, who said he dreamed of seeing his club without foreigners. Regarding this, Giulianotti and Robertson (2004) note that this process of globalization in football has as its counterpart a growing sense of dispossession among fans, and stress the importance of maintaining the balance between globalization and identity.

Another line of critique is the negative impact for national teams of excessive volumes of foreign players: despite the Premier League being considered one of the best leagues in the world, and English clubs among the strongest in Europe, the English team does not achieve similar success. Several voices blame the increase of foreign players in the Premier League clubs for such weak National team results. In this context, several football

\footnotetext{
4 The Bosman ruling established freedom of movement football players, as workers, within the European Union. In December 1995, the European Court of Justice ruled that the provision, whereby out-of-contract players could only move between two clubs in different European (EU) countries if a transfer fee was agreed between the clubs, was incompatible with Article 48 of the "Treaty of Rome" which relates to freedom of movement of labor. Moreover, Article 48 was also ruled as incompatible with restrictions on the number of foreign players permitted in a team.

The Bosman jurisprudence was later extended to citizens of European countries that were not European Union member states by the Malaja, Kolpak and Simutenkov cases and to citizens of African, Caribbean and Pacific countries by the 2000 Cotonou agreement.

5 The "Big Five" are England, Spain, Germany, Italy and France.
} 
federations restrict the entry of foreign players, aiming to ensure the success of national football teams. With the intention of restricting the number of foreign players, in 2000, FIFA and UEFA sought support from the European Parliament to amend the Amsterdam Treaty, and recognize football as a cultural activity to stop the effects of the Bosman ruling. ${ }^{6}$

In 2008, FIFA approved the application of the "6 +5 rule" to force clubs to field six players eligible for the national team to protect the identity of national teams. However, the European Commissioner for Employment, Valdmiri Špidla, challenged this idea because "players are workers and the principles of free movement must be respected. The rule of ' $6+5$ ' constitutes direct discrimination" 7 and that the European Commission would take legal action against any country that approved the controversial proposal by FIFA to limit the number of foreigners in football clubs.

Finally, a different rule was created for the "protection of young players": since 2008/09, clubs in the UEFA Champions League and UEFA Europa League are required to include a minimum of eight homegrown players of the country in a squad limited to 25 players. ${ }^{8}$ UEFA defines "homegrown players in a country" as those who, regardless of their nationality, have been trained by such club or by another club in the same national association for at least three years when the player was between 15 and 21 years old. UEFA regulations have no conditions of nationality, since those conditions would be illegal in the European Union (the Bosman ruling).

In line with this European policy, many countries have restrictions on foreign players, varying extensively within the same area. As for Latin America, Argentina allows only four foreigners in the club, whereas in Brazil the number is three, in Chile seven, five for Mexico and six for Peruvian clubs. European countries face a huge diversity of rules for players from EU-countries and non-EU countries: no quota for non-EU-players (Austria, Belgium, England ${ }^{9}$, Germany, Poland, Portugal, Scotland, Serbia, Wales, The Netherlands), no quota for non-EU-players but only a certain amount can be brought to the games (Czech Republic, Croatia, Denmark, Finland, Hungary, Iceland, Russia, Sweden, Slovakia) and a limited amount of foreigners/non EU players (Belarus, Bulgaria, France, Greece, Israel, Italy, Norway, Romania, Spain, Turkey). For example, Spain only allows for three non-EU players. The differences between EU and non-EU players have

\footnotetext{
${ }^{6}$ As established by the EU treaties, the principle of free movement may not apply to cultural activities, since culture is one of the areas, along with defense, which are not subject to these rules, considering them outside the economic space and responsibility of each State. For this reason, some governments of EU countries have requested the declaration of sport as a cultural activity, with the aim of maintaining this area outside the regulations imposed by the court.

7 Statement of Commissioner Vladimir Špidla regarding FIFA's “6+5” rule, accessible at http://ec.europa.eu/social/main.jsp?langId=en\&catId=89\&newsId=424\&furtherNews=yes

${ }^{8}$ Clubs have no obligation to play a certain number of homegrown players in a match in the national league.

${ }^{9}$ England only allows the entry of foreign players if they play regularly in some of the best 70 national football teams of the world.
} 
resulted in seeking an EU passport for players as a way to avoid restrictions and to be part of the more competitive leagues in the world. ${ }^{10}$

As reported above, most academic literature addressing this phenomenon is concentrated on analyzing the impact of foreign players on a national team's performance. To the best of our knowledge, to date only Karaka (2008) has focused on the study of the impact of international migration on club performance in a small data set and with no information at the club level. Our work expands current knowledge by considering a comprehensive and wide database at the international level of about one thousand clubs worldwide.

\section{FROM THEORY TO EMPIRICS}

Bernard and Busse (2004) develop a theoretical framework to analyze the determinants of success in sport, specifically at the Olympic Games. On the other hand, many other works have studied the determinants of national football team success. ${ }^{11}$ Gásquez and Royuela (2016) apply the model developed by Bernard and Busse (2004) to a national football team's performance. We follow this theoretical framework, where the empirical expression is as follows: ${ }^{12}$

$$
S_{i}=\beta_{0}+\beta_{1} \ln N_{i}+\beta_{2} \ln W_{i}+\beta_{3} \ln Y_{i}+\beta_{4} I_{i}+u_{i}
$$

Where $S_{i}$ refers to football success, $N_{i}$ to population, $Y_{i}$ to economic resources, $W_{i}$ to warm temperature, $I_{i}$ to football-related institutions at country level, and $u_{i}$ is error term. This model assumes that the talent of players is randomly distributed and consequently we would expect success to be proportional to population. Still, despite having a large population, wealthy countries are more likely to have public and/or private organizations willing to invest in improving good players. The variable for temperature follows Hoffman et al. (2002), who claim that the optimal mean annual temperature for sporting practice is $14^{\circ} \mathrm{C}$ and that shifts from this temperature can hinder success. Football rather than political institutions (Leeds and Leeds, 2009) may be connected with football performance (as in Gásquez and Royuela, 2016).

These variables are suitable for studies at national team level, but they may not be enough for analyzing performance of clubs, as they do not capture differences within national leagues. Consequently, we adapt these variables to analyze the determinants of

\footnotetext{
${ }^{10}$ Some of the most striking cases of passport forgeryto obtain dual citizenship are: the Argentinian Veron, convicted of falsifying his Italian passport for an alleged great grandfather, the Brazilian Dida and Uruguayan Alvaro Recoba who received penalties for passport fraud. Many other players have found a way to obtain dual nationality. For instance, Spain allows for citizenship after several years of legal and continuous residence (just two years for nationals of Latin American countries, Andorra, Philippines, Equatorial Guinea, Portugal or persons of Sephardic origin).

${ }^{11}$ Hoffman et al. (2002), Houston and Wilson (2002), Torgler (2004a), Torgler (2004b), Torgler (2004c), Hoffman et al. (2006), Macmillan and Smith (2007), Gelade and Dobson (2007), Leeds and Leeds (2009), Yamamura (2009), Binder and Findlay (2012), Berlinschi et al. (2013), Allan and Moffat (2014) and Jacobs (2014) have studied the determinants of the success of national football teams.

${ }^{12}$ See Additional Material number 1 for model development.
} 
performance at the club level. Castellanos et al. (2007) analyze the determinants of success taking cities instead of countries as units of analysis. They consider that success at club level is a function of the size and wealth of its city. ${ }^{13}$ They consider these factors using population and local GDP per capita. These authors end their work by arguing that future studies should address the importance of inherently non-economic factors of the city/club, such as culture, weather conditions, institutions or historical excellence (tradition) in the context of football performance.

In addition to considering GDP per capita as a proxy of socioeconomic conditions, we prefer to consider the economic 'power' of every club, proxying the capacity to hire more and better (foreign) players. Szymanski (2003) and Osso and Szymansky (1991) reports a positive relationship between expenditure on player's wages,transfers and position for twelve English Clubs. Likewise, Fløtnes (2011) argues that the more important factors for clubs' success are player wages and financial resources through operating income. When competing in the elite division or at international level, access to financial resources partly determines how successful a football club can be. The Economist (2014) illustrates a strong link between the amount spent on wages and the points won by 34 English clubs that played in the top division between 1996 and $2014 .^{14}$

For these reasons, we focus the explanatory variables of the equation (1) in our study at the club level by considering $Y_{i}$, the economic resources of the club, $N_{i}$, the population of the city where each club is located, $W_{i}$, an index that takes into account the average temperature of each city, and $I_{i}$, an indicator of local football institutions, that we proxy with confederations and country dummies.

In addition to these variables, we consider the proportion of foreign football players, $M_{i}$, which allows us to capture the impact of migration on football clubs' success. We cannot distinguish with our approach between learning, sharing and matching. Rather, we simply account for a global impact of this variable. We finally add more controls by considering the social engagement of clubs through the capacity of the Stadium, $\operatorname{Cap}_{i}$, as a proxy of attendance.

Finally, then, our equation becomes:

$$
S_{i}=\beta_{0}+\beta_{1} M_{i}+\beta_{2} \ln N_{i}+\beta_{3} W_{i}+\beta_{4} \ln Y_{i}+\beta_{5} I_{i}+\beta_{6} \ln \operatorname{Cap}_{i}+u_{i}
$$

\section{DATA}

Our empirical strategy relies on the use of a worldwide dataset. It is difficult, though, to find official comparable statistics for capturing success of football clubs in an

\footnotetext{
${ }^{13}$ Walker (1986), Burger and Walters (2003), Troelsen (2005) and Fløtnes (2011) argue that the most populous cities offer a greater internal potential market for their football teams.

${ }^{14}$ As anecdotal evidence, Sam Allardyce, former manager of West Ham United and English football manager, came up with a straightforward explanation for footballing performance: "Where you finish in the league depends on the money you've spent. It's a statistical fact, that.”
} 
international environment. Other works in football literature have worked with points in domestic leagues, rankings at the European level, etc., which makes it difficult to make worldwide comparisons. Our final database considers 971 clubs from the First Divisions of 71 Leagues. $^{15}$ We finally rely on the Elo rating score published by www.footballdatabase.com. The data set referred to is February 2016. This ranking follows the methodology Elo Rating, also followed in Gasquez and Royuela (2016), who show its advantages over official scores, such as FIFA ranking. ${ }^{16}$ The top ten clubs according to this ranking in February 2016 are displayed in Table 1, while Figure 1 shows the boxplot of the clubs according to every football confederation ${ }^{17}$.

Table 1. World top 10 clubs according to Elo Ratig score. February 2016.

\begin{tabular}{|c|c|c|c|}
\hline League & Club & Ranking & $\begin{array}{c}\text { Elo } \\
\text { Points }\end{array}$ \\
\hline Spain & FC Barcelona & 1 & 2082 \\
\hline Germany & Bayern Munich & 2 & 1989 \\
\hline Spain & Real Madrid & 3 & 1967 \\
\hline France & Paris Saint-Germain & 4 & 1958 \\
\hline Italy & Juventus FC & 5 & 1942 \\
\hline Spain & Atlético Madrid & 6 & 1908 \\
\hline Italy & SSC Napoli & 7 & 1855 \\
\hline England & Arsenal FC & 8 & 1822 \\
\hline England & Tottenham Hotspur & 9 & 1818 \\
\hline Germany & Borussia Dortmund & 10 & 1810 \\
\hline
\end{tabular}

\section{Figure 1. Box plot of Elo rating score by Football Confederation}

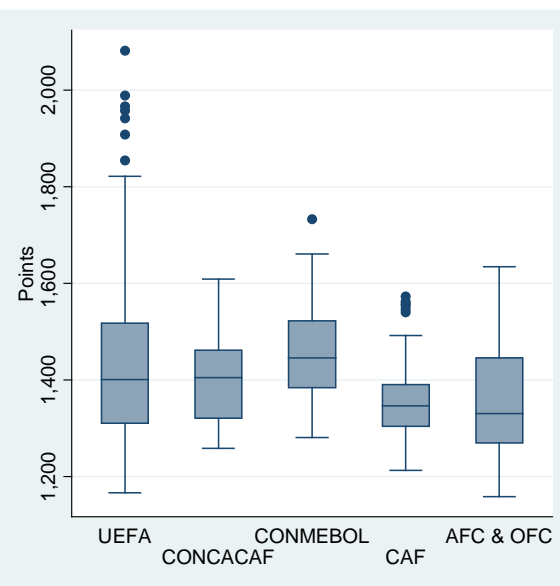

Table 2. Top clubs and national leagues by share of foreign players

\begin{tabular}{|l|c|}
\hline Club (National League) & $\begin{array}{c}\text { (\%) Foreign } \\
\text { players }\end{array}$ \\
\hline AS Monaco (France) & $100 \%$ \\
\hline Watford FC (England) & $93.10 \%$ \\
\hline Swansea City (England) & $91.30 \%$ \\
\hline Inverness Caledonian Thistle FC (Scotland) & $88.00 \%$ \\
\hline NK Zavrc (Slovenia) & $85.19 \%$ \\
\hline FC Vaduz (Switzerland) & $84.62 \%$ \\
\hline Chelsea FC (England) & $84.00 \%$ \\
\hline Stoke City (England) & $84.00 \%$ \\
\hline Manchester City (England) & $83.33 \%$ \\
\hline Inter Milan (Italy) & $82.61 \%$ \\
\hline
\end{tabular}

\begin{tabular}{|l|c|}
\hline National League & $\begin{array}{c}\text { (\%) Foreign } \\
\text { players }\end{array}$ \\
\hline Canada & $77.98 \%$ \\
\hline England & $69.34 \%$ \\
\hline Cyprus & $58.31 \%$ \\
\hline Belgium & $56.36 \%$ \\
\hline Portugal & $55.65 \%$ \\
\hline Italy & $55.48 \%$ \\
\hline Luxembourg & $55.43 \%$ \\
\hline Switzerland & $52.41 \%$ \\
\hline Germany & $49.54 \%$ \\
\hline France & $49.30 \%$ \\
\hline
\end{tabular}

The explanatory variables refer to 2015. To find the proportion of foreign players, we used information at www.transfermarkt.es. Table 2 displays the top ten clubs and top ten leagues by share of foreign football players, while Figure 2 displays the box-plot of this variable by confederation. On average, the confederation with the largest share of foreign-

\footnotetext{
15 Appendix 1 lists the considered football leagues.

${ }^{16}$ A detailed analysis of the methodology for calculating the Elo rating is shown in Additional Material 2.

${ }^{17}$ UEFA, CONCACAF, CONMEBOL, AFC, CAF, and OFC. Supporting Information Additional Material 3 provides details of the countries in each confederation.
} 
born football players is UEFA (35\%), followed by CONCACAF (34\%), AFC and OFC (19\%), CONMEBOL (12\%) and CAF (11\%). It is important to compare these figures against global ones: about 200 million people in the world, around 3\% of total world population, live outside their country of birth. As in football, the proportion of international immigrants is greater in developed countries: they represent more than 12 percent of the total population in OECD countries.

\section{Figure 2. Box plot of the share of foreign players, by Football Confederation}

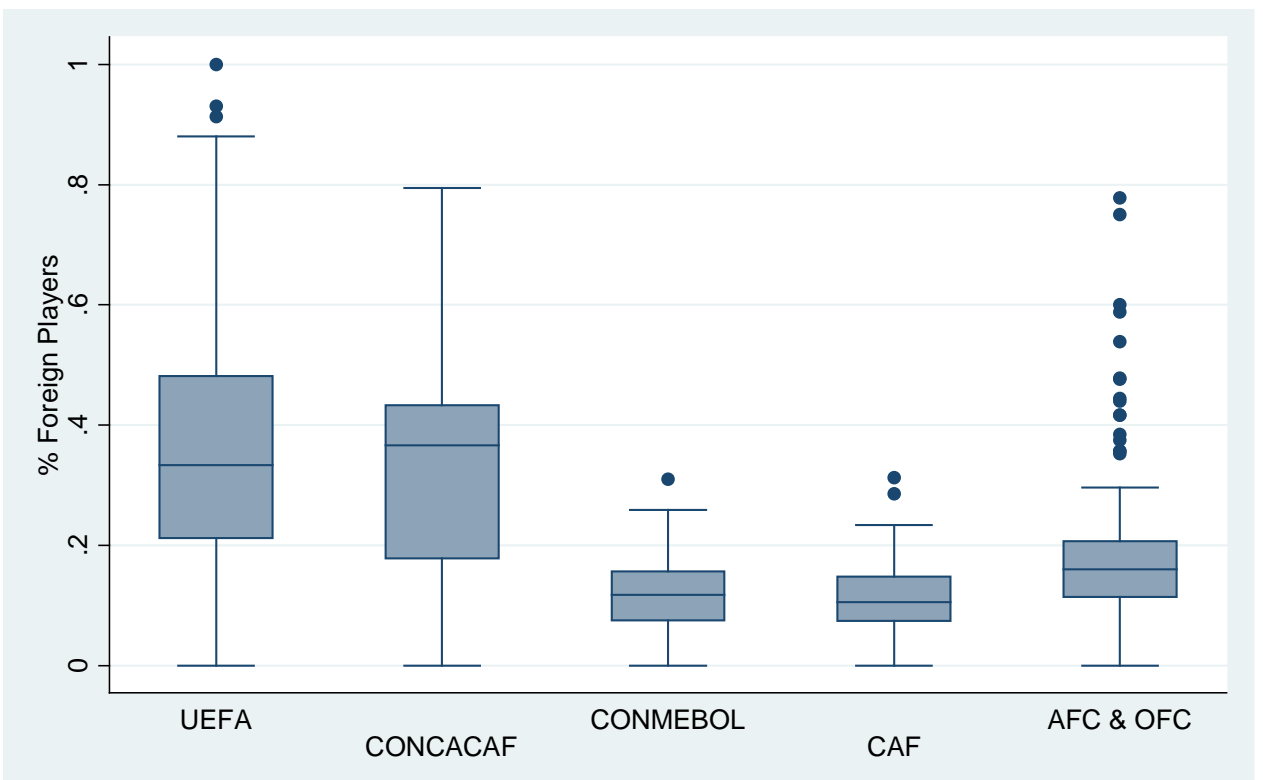

The proxy we consider of the economic power of football clubs is the market value published by www.transfermarkt.es. This variable is highly correlated with the budget of clubs and consequently can be used to proxy the total wage bill. ${ }^{18}$ To know which city the football club is from, we use www.soccerway.com information. City population data comes from Wikipedia, and refers to the administrative definition of the city rather than corresponding to the metropolitan of functional urban area. We follow Hoffman et al. (2002) and consider as weather indicator an index considering the deviation from the optimal mean annual temperature for sporting performance, which is settled at $14^{\circ} \mathrm{C}$. Thus, our weather variables is computed as $W_{i}=(\text { Temperature }-14)^{2}$. The Average city temperature is extracted from http://www.weatherbase.com. We will consider a list of country (league) dummies to capture differentiated football-related institutions. The capacity of the stadium is obtained mostly from www.soccerway.com, being complemented using Wikipedia. The same sources are used to find the year of foundation of the club, a variable that we will used later for identification issues, together with the average player age at each club, also obtained from www.transfermarkt.es. Appendix 2 summarizes the description and sources of all considered variables, and Table 3 reports the descriptive statistics of the considered variables.

\footnotetext{
${ }^{18}$ Additional Material 5 displays the correlation between market value and to see why the market value of the Squad is a good Proxy of the budget of the clubs.
} 
At this stage, we look at the correlation between the Elo ranking score and the share of foreign players. Figure 3 displays the scatter plot between these two variables for the 971 considered clubs. The left panel considers all information, the central panel the average for every national league, and the right panel plots the information of all clubs once national averages are removed (within transformation). In the first case the correlation is 0.36 , which increases to 0.44 between countries and shrinks to 0.28 when national averages are discounted (correlations for the log of the Elo rating are very similar). Consequently, we have a first insight into a positive relationship between these two variables, which is much stronger at the national level than within each national league. The next step will try to find out if this correlation holds once we control for other factors.

Table 3. Descriptive statistics

\begin{tabular}{lccccccc}
\multicolumn{1}{c}{ Variable } & Obs. & Mean & Std. Dev. & Min. & Max. & $\begin{array}{c}\text { Corr(Xi, } \\
\text { ln Points) }\end{array}$ & $\begin{array}{c}\text { Corr(Xi, \% } \\
\text { For. Pl.) }\end{array}$ \\
\hline Elo Points & 971 & 1414.9 & 133.77 & 1159 & 2082 & & \\
ln Elo Points & 971 & 7.251 & 0.091 & 7.055 & 7.641 & & \\
\% Foreign Players & 971 & 0.277 & 0.196 & 0 & 1 & 0.359 & \\
Market Value & 971 & 26.14 & 63.01 & 0.025 & 704.8 & 0.623 & 0.434 \\
Population & 970 & $1,396,643$ & $2,965,882$ & 25,333 & $24,152,700$ & 0.125 & -0.079 \\
Weather & 971 & 33,59 & 43,42 & .0001 & 289,00 & -0.125 & -0.139 \\
Stadium Capacity & 971 & $22,714.7$ & $18,805.9$ & 368 & 105,064 & 0.538 & 0.134 \\
Year Founded & 968 & 1,943 & 36.6 & 1,863 & 2,014 & -0.378 & -0.171 \\
Age & 971 & 25.6 & 1.66 & 18.5 & 33.6 & 0.082 & 0.191 \\
\hline
\end{tabular}

Figure 3. Scatter plots between Elo ranking score and the Share of Foreign Players



\section{RESULTS}


The estimation strategy tries to avoid endogeneity problems because of a possible causal link between the percentage of foreigners and performance of football clubs. We have obtained the data of foreign players playing at a club since September 2015 and the ranking of the club in February 2016. ${ }^{19}$ Thus, the causality is from the variable number of foreign players to success in football clubs, and not vice versa. Nevertheless, we admit that such variables may have some time series persistence, and consequently some reverse causality can exist in the data, together with the omitted variables problem. In order to solvethese problems, at least partially, we incorporate an instrumental variable approach based on a two-step procedure following Brückner $(2012,2013)$ and Castells-Quintana (2016). We use the year of foundation of each club to build instruments for football success in an equation explaining the share of international football migrants. Later we use the residual of this equation as an instrument for the share of football migrants in our main equation, together with the average age of players in every club. We explain this identification strategy in appendix 3.

Table 4 displays the results of the main model where we use the variables in logs. We introduce variables sequentially and columns 1 to 7 display OLS estimates, while columns 8 to 11 show IV estimates. We can see how in a first stage the share of foreign players is positively associated with clubs' success, even if external components are controlled for (columns 1 and 2). Nevertheless, when financial and market potential variables are introduced (columns 3 and 4), model adjustment improves dramatically and the parameter for the share of foreign players turns significant and negative, which we interpret as a clear sign of the strength of financial aspects in sport success. When we introduce institutions in columns 5 (confederations dummies) and 6 (country dummies), the share of foreign players becomes insignificant. One can interpret this result in terms of the importance of financial variables and national regulations as main drivers on international football rankings. When national regulations are controlled, competition for foreign players is balanced within every country and this factor becomes negligible. Clubs’ performance basically depends on their financial health. To be clear: while those leagues with a higher share of foreign players have better ratings than leagues with less imported players, within each league where all clubs face the same type of restrictions in hiring foreign players, this factor finally becomes negligible.

Nevertheless, at this stage we have not accounted for reverse causality. Columns 7 to 10 report IV estimates using as instruments the residual of the two-step procedure based on instrumenting the 2010 Elo rating when explaining the September 2015 share of foreign players. This generated instrument is used together with the average age of all football players in each club (and its square) in columns 8 to 10 to report the over identification statistics. This set of regressions report again a non-significant parameter, which we understand as a sort of robustness check of the previous results. Still, the insignificance of the parameter of the interest variable might be the result of non-linearities or an omitted

\footnotetext{
${ }^{19}$ This indicator considers the results of recent months. For example, on 14.02.2016 (date of obtaining the data of this ranking) Leicester City was Leader of the Premier League and consequently was ranked 15th, while the same week of the previous year it ranked 416th.
} 
variables problem. We have performed a number of regressions, available upon request, excluding variables with non-significant parameters (Population and Weather), including the square of the log of the Stadium Capacity and even the ratio between the Market value and the Stadium Capacity. The share of foreign players was not significant in any of these regressions. We finally included the square of the share of foreign players in a list of regressions with permutations of the other control variables. These regressions never reported a significant parameter for the share of foreign players. We admit, though, that as in any empirical work, some relevant variables, such as quality of foreign players or the leagues, are lacking. Narrowing the scope of analysis, for instance looking at a specific territory or confederation, would allow to include new information, an aspect that we leave for further research.

We investigate next if our result is a global outcome or if it is specific to some World regions or Football confederations. We perform additional regressions separated by Football confederations. Both OLS and IV estimates are presented in table 5, including in all cases national dummies. We see there that, in general, the share of international football players is not significantly associated with clubs' success. This is an additional proof of the small impact of this variable compared with the economic ones, including the market value and the capacity of the stadium. We also included the square of the share of football players (results not reported), with similar results.

We finally check for robustness by using the ranking of clubs rather than Elo points. We also use the Elo rating rather than the log of the index. The results (not reported here for brevity but displayed in Additional Material 8) basically replicate former results, with the exception of the marginally significant parameter for the CONCACAF subsample for the model using the ranking rather than the Elo points. Overall, then, the benefits of having a larger share of foreign players does not exist either in the global sample or in any confederation. 
Table 4. Estimation results

\begin{tabular}{|c|c|c|c|c|c|c|c|c|c|c|}
\hline & $\begin{array}{l}(1) \\
\text { OLS }\end{array}$ & $\begin{array}{l}(2) \\
\text { OLS }\end{array}$ & $\begin{array}{c}(3) \\
\text { OLS }\end{array}$ & $\begin{array}{c}4) \\
\text { OLS }\end{array}$ & $\begin{array}{c}5) \\
\text { OLS }\end{array}$ & $\begin{array}{l}6) \\
\text { OLS }\end{array}$ & $\begin{array}{c}(7) \\
2 S L S\end{array}$ & $\begin{array}{c}(8) \\
2 S L S\end{array}$ & $\begin{array}{c}(9) \\
\text { 2SLS }\end{array}$ & $\begin{array}{c}(10) \\
\text { 2SLS }\end{array}$ \\
\hline$\%$ Foreign players & $\begin{array}{c}0.1658 * * * \\
(0.039)\end{array}$ & $\begin{array}{c}0.1780 * * * \\
(0.034)\end{array}$ & $\begin{array}{c}-0.0127 \\
(0.030)\end{array}$ & $\begin{array}{c}-0.0435 * * \\
(0.022)\end{array}$ & $\begin{array}{c}-0.0159 \\
(0.019)\end{array}$ & $\begin{array}{l}0.0174 \\
(0.015)\end{array}$ & $\begin{array}{c}-0.0120 \\
(0.014)\end{array}$ & $\begin{array}{c}-0.0120 \\
(0.013)\end{array}$ & $\begin{array}{c}-0.0122 \\
(0.013)\end{array}$ & $\begin{array}{c}-0.0122 \\
(0.013)\end{array}$ \\
\hline In Population & & $\begin{array}{c}0.0152 * * * \\
(0.002)\end{array}$ & $\begin{array}{l}0.0002 \\
(0.002)\end{array}$ & $\begin{array}{r}-0.0000 \\
(0.002)\end{array}$ & $\begin{array}{l}0.0004 \\
(0.002)\end{array}$ & $\begin{array}{l}0.0014 \\
(0.001)\end{array}$ & $\begin{array}{l}0.0012 \\
(0.001)\end{array}$ & $\begin{array}{l}0.0012 \\
(0.001)\end{array}$ & $\begin{array}{l}0.0012 \\
(0.001)\end{array}$ & $\begin{array}{l}0.0012 \\
(0.001)\end{array}$ \\
\hline Weather Index & & $\begin{array}{c}-0.0002^{*} \\
(0.000)\end{array}$ & $\begin{array}{l}0.0001 \\
(0.000)\end{array}$ & $\begin{array}{l}0.0001 \\
(0.000)\end{array}$ & $\begin{array}{l}0.0001 \\
(0.000)\end{array}$ & $\begin{array}{c}-0.0000 \\
(0.000)\end{array}$ & $\begin{array}{l}-0.0000 \\
(0.000)\end{array}$ & $\begin{array}{c}-0.0000 \\
(0.000)\end{array}$ & $\begin{array}{c}-0.0000 \\
(0.000)\end{array}$ & $\begin{array}{c}-0.0000 \\
(0.000)\end{array}$ \\
\hline ln Market value & & & $\begin{array}{c}0.0510^{* * *} \\
(0.008)\end{array}$ & $\begin{array}{c}0.0212 * * * \\
(0.008)\end{array}$ & $\begin{array}{c}0.0196 * * \\
(0.008)\end{array}$ & $\begin{array}{c}0.0563 * * * \\
(0.009)\end{array}$ & $\begin{array}{c}0.0577 * * * \\
(0.008)\end{array}$ & $\begin{array}{c}0.0577^{* * *} \\
(0.006)\end{array}$ & $\begin{array}{c}0.0577 * * * \\
(0.006)\end{array}$ & $\begin{array}{c}0.0577 * * * \\
(0.006)\end{array}$ \\
\hline ln Market value ${ }^{2}$ & & & & $\begin{array}{c}0.0068 * * * \\
(0.001)\end{array}$ & $\begin{array}{c}0.0067 * * * \\
(0.001)\end{array}$ & $\begin{array}{c}0.0047 * * * \\
(0.001)\end{array}$ & $\begin{array}{c}0.0048 * * * \\
(0.001)\end{array}$ & $\begin{array}{c}0.0048^{* * *} \\
(0.001)\end{array}$ & $\begin{array}{c}0.0048 * * * \\
(0.001)\end{array}$ & $\begin{array}{c}0.0048^{* * *} \\
(0.001)\end{array}$ \\
\hline ln Stadium Capacity & & & $\begin{array}{c}0.0097 * * \\
(0.004)\end{array}$ & $\begin{array}{c}0.0092 * * \\
(0.004)\end{array}$ & $\begin{array}{c}0.0092 * * * \\
(0.003)\end{array}$ & $\begin{array}{c}0.0099 * * * \\
(0.003)\end{array}$ & $\begin{array}{c}0.0098 * * * \\
(0.003)\end{array}$ & $\begin{array}{c}0.0098^{* * *} \\
(0.002)\end{array}$ & $\begin{array}{c}0.0098 * * * \\
(0.002)\end{array}$ & $\begin{array}{c}0.0098^{* * *} \\
(0.002)\end{array}$ \\
\hline Confederation Dummies & NO & NO & NO & NO & YES & NO & NO & NO & NO & NO \\
\hline Country Dummies & NO & NO & NO & NO & NO & YES & YES & YES & YES & YES \\
\hline $\begin{array}{l}\text { Kleibergen-Paap rk LM s } \\
\text { Hansen J-Statistic (p-val) }\end{array}$ & atistic & & & & & & & & $\begin{array}{l}170.8(0.000) \\
1.797(0.180)\end{array}$ & $\begin{array}{l}170.9(0.000) \\
1.878(0.171)\end{array}$ \\
\hline Observations & 971 & 970 & 970 & 970 & 970 & 970 & 970 & 970 & 970 & 970 \\
\hline R-squared & 0.126 & 0.246 & 0.604 & 0.658 & 0.680 & 0.807 & 0.806 & 0.806 & 0.806 & 0.806 \\
\hline
\end{tabular}

Note: Robust standard errors clustered by country in parentheses. ${ }^{* * *} \mathrm{p}<0.01,{ }^{* *} \mathrm{p}<0.05,{ }^{*} \mathrm{p}<0.1$. Equations (8) to (10) report not-clustered robust standard errors to get the over-identification statistics. Columns (7) and (8) use the generated residual resulting from the two-step Brückner strategy described in appendix 3. Columns (9) and (10) add the average age of players and its square respectively, what allows for computing the over-identification statistic. KP refers to the under-identification Kleibergen-Paap LM statistic, while the J statistic corresponds to the over-identification Hansen J-Statistic. 
Table 5. Estimation results by confederation.

\begin{tabular}{|c|c|c|c|c|c|c|c|c|c|c|}
\hline & $\begin{array}{c}(1) \\
\text { UEFA }\end{array}$ & $\begin{array}{c}(2) \\
\text { CONMEBOL }\end{array}$ & $\begin{array}{c}(3) \\
\text { CONCACAF }\end{array}$ & $\begin{array}{c}4) \\
\text { CAF }\end{array}$ & $\begin{array}{c}5) \\
\text { AFC - OFC }\end{array}$ & $\begin{array}{c}(6) \\
\text { UEFA }\end{array}$ & $\begin{array}{c}(7) \\
\text { CONMEBOL }\end{array}$ & $\begin{array}{c}(8) \\
\text { CONCACAF }\end{array}$ & $\begin{array}{c}\text { (9) } \\
\text { CAF }\end{array}$ & $\begin{array}{c}(10) \\
\text { AFC - OFC }\end{array}$ \\
\hline & OLS & OLS & OLS & OLS & OLS & IV & IV & IV & IV & IV \\
\hline \% Foreign players & $\begin{array}{l}0.00643 \\
(0.0153)\end{array}$ & $\begin{array}{l}0.00138 \\
(0.0886)\end{array}$ & $\begin{array}{c}0.0852 \\
(0.0630)\end{array}$ & $\begin{array}{c}0.169 * \\
(0.0869)\end{array}$ & $\begin{array}{c}0.0189 \\
(0.0393)\end{array}$ & $\begin{array}{l}-0.0120 \\
(0.015)\end{array}$ & $\begin{array}{l}-0.0003 \\
(0.089)\end{array}$ & $\begin{array}{l}0.0465 \\
(0.060)\end{array}$ & $\begin{array}{l}0.0232 \\
(0.083)\end{array}$ & $\begin{array}{c}-0.0631 \\
(0.046)\end{array}$ \\
\hline ln Population & $\begin{array}{c}0.00201 \\
(0.00135)\end{array}$ & $\begin{array}{c}0.00104 \\
(0.00221)\end{array}$ & $\begin{array}{c}0.00370 \\
(0.00568)\end{array}$ & $\begin{array}{l}-0.000964 \\
(0.00209)\end{array}$ & $\begin{array}{c}0.00318 \\
(0.00362)\end{array}$ & $\begin{array}{l}0.0018 \\
(0.001)\end{array}$ & $\begin{array}{l}0.0010 \\
(0.002)\end{array}$ & $\begin{array}{l}0.0038 \\
(0.005)\end{array}$ & $\begin{array}{l}-0.0008 \\
(0.002)\end{array}$ & $\begin{array}{l}0.0019 \\
(0.003)\end{array}$ \\
\hline Weather Index & $\begin{array}{c}4.13 \mathrm{e}-05 \\
(9.65 \mathrm{e}-05)\end{array}$ & $\begin{array}{c}3.67 \mathrm{e}-05 \\
(0.000109)\end{array}$ & $\begin{array}{l}-0.000275 \\
(0.000164)\end{array}$ & $\begin{array}{c}7.29 \mathrm{e}-05 \\
(0.000159)\end{array}$ & $\begin{array}{c}-1.10 \mathrm{e}-05 \\
(0.000140)\end{array}$ & $\begin{array}{l}0.0000 \\
(0.000)\end{array}$ & $\begin{array}{l}0.0000 \\
(0.000)\end{array}$ & $\begin{array}{c}-0.0003^{*} \\
(0.000)\end{array}$ & $\begin{array}{l}0.0000 \\
(0.000)\end{array}$ & $\begin{array}{l}-0.0000 \\
(0.000)\end{array}$ \\
\hline ln Market value & $\begin{array}{c}0.0727 * * * \\
(0.00812)\end{array}$ & $\begin{array}{c}0.0910 * * * \\
(0.0292)\end{array}$ & $\begin{array}{c}0.0348 \\
(0.0760)\end{array}$ & $\begin{array}{c}0.0518 * * * \\
(0.00558)\end{array}$ & $\begin{array}{l}-0.00958 \\
(0.0136)\end{array}$ & $\begin{array}{c}0.0742 * * * \\
(0.008)\end{array}$ & $\begin{array}{c}0.0910 * * * \\
(0.028)\end{array}$ & $\begin{array}{l}0.0409 \\
(0.069)\end{array}$ & $\begin{array}{c}0.0535 * * * \\
(0.006)\end{array}$ & $\begin{array}{l}-0.0038 \\
(0.014)\end{array}$ \\
\hline ln Market value ${ }^{2}$ & $\begin{array}{c}0.00298^{* * *} \\
(0.00109)\end{array}$ & $\begin{array}{l}-0.00781 \\
(0.00510)\end{array}$ & $\begin{array}{l}0.00313 \\
(0.0148)\end{array}$ & $\begin{array}{r}0.0134 * * * \\
(0.00120)\end{array}$ & $\begin{array}{c}0.0295 * * * \\
(0.00463)\end{array}$ & $\begin{array}{c}0.0030 * * * \\
(0.001)\end{array}$ & $\begin{array}{l}-0.0078 \\
(0.005)\end{array}$ & $\begin{array}{l}0.0025 \\
(0.013)\end{array}$ & $\begin{array}{c}0.0138 * * * \\
(0.001)\end{array}$ & $\begin{array}{c}0.0285^{* * * *} \\
(0.005)\end{array}$ \\
\hline ln Stadium Capacity & $\begin{array}{l}0.00565^{*} \\
(0.00321)\end{array}$ & $\begin{array}{c}0.0196 * * * \\
(0.00682)\end{array}$ & $\begin{array}{c}0.0171 \\
(0.0124)\end{array}$ & $\begin{array}{l}0.000219 \\
(0.00401)\end{array}$ & $\begin{array}{c}0.00907 \\
(0.00915)\end{array}$ & $\begin{array}{c}0.0057^{*} \\
(0.003)\end{array}$ & $\begin{array}{c}0.0196 * * * \\
(0.006)\end{array}$ & $\begin{array}{l}0.0169 \\
(0.011)\end{array}$ & $\begin{array}{l}0.0007 \\
(0.004)\end{array}$ & $\begin{array}{l}0.0087 \\
(0.009)\end{array}$ \\
\hline $\begin{array}{l}\text { KP statistic (p-val) } \\
\text { J-Statistic (p-val) }\end{array}$ & & & & & & $\begin{array}{l}131.2(0.000) \\
5.517(0.063)\end{array}$ & $\begin{array}{l}36.56(0.000) \\
3.242(0.198)\end{array}$ & $\begin{array}{l}9.800(0.020) \\
0.427(0.808)\end{array}$ & $\begin{array}{l}30.72(0.000) \\
2.680(0.262)\end{array}$ & $\begin{array}{l}13.52(0.004) \\
1.639(0.441)\end{array}$ \\
\hline Country dummies & YES & YES & YES & YES & YES & YES & YES & YES & YES & YES \\
\hline Observations & 571 & 129 & 50 & 94 & 124 & 571 & 129 & 50 & 95 & 125 \\
\hline R-squared & 0.715 & 0.603 & 0.427 & 0.596 & 0.556 & 0.858 & 0.630 & 0.589 & 0.706 & 0.688 \\
\hline
\end{tabular}

the average Age (and its square) of players in every club. KP refers to the under-identification Kleibergen-Paap LM statistic, while the J statistic corresponds to the overidentification Hansen J-Statistic. 


\section{CONCLUSIONS}

This work analyses the socio-economic determinants of sporting success of football clubs in a worldwide cross-section sample, and especially inspects the effect of the proportion of foreign players when other factors are controlled for. We use the Elo rating as indicator for the world ranking of close to one thousand clubs in 71 leagues. We use a two-step procedure as an identification strategy: in a regression explaining the proportion of foreign football players in 2015 we instrument the Elo rating in 2010 by means of the year of foundation of every club together with the local conditions for playing football. The residual of this equation is later used as an instrument of the share of foreign players in a regression explaining the Elo rating in 2016.

We observe that, on average, leagues with higher proportions of foreign players are the ones with better positioned clubs. On the contrary, within each league, having more foreign players has a negligible impact on clubs’ performance.

As expected, we find that the fundamental explanatory variable of clubs' success is money. Our key finding is that having more foreign football players favors the performance of clubs at an international level: national regulations allowing more foreign players will result in better performance of these clubs in an international framework. Nevertheless, such influence vanishes within each national league, where each club faces the same level of restrictions in hiring foreign talent. In the end having better players will be the result of financial constraints. We believe that our work can be improved by including relevant variables such as the quality of the players and even dealing with the quality of the leagues. Working with a panel data set would also allow for controlling for non-observable variables at the club level.

\section{REFERENCES}

Allan, G. J. and Moffat, J. (2014). "Muscle drain versus gain in association football: technology transfer through player migrations and manager immigration.” Applied Economic Letters, 21(7), 490-493.

Alvarez, J., Forrest, D. and Sanz, I. (2011). "Impact of importing foreign talent on performance levels of local co-workers.” Labour Economics, 18, 287-96.

Baur, D. G. and Lehmann, S. (2007). "Does the mobility of football players influence the success of the national team?” IIIS Discussion Paper No. 217, Institute for International Integration Studies, Dublin.

Behrens, K., and Robert-Nicoud, F. (2014). "Survival of the fittest in cities: Urbanisation and inequality.” The Economic Journal, 124(581): 1371-1400. 
Berlinschi, R., Schokkaert, J. and Swinnen, J. (2013). "When drains and gains coincide: migration and international football performance.” Labour Economics, 21, 1-14.

Bernard, A. B. and Busse, M. R. (2004). "Who wins the Olympic Games: economic resources and medal total.” The Review of Economic and Statistics, 86(1), 413-417.

Binder, J. J. and Findlay, M. (2012). "The effects of the Bosman ruling on national and club teams in Europe.” Journal of Sports Economics, 13, 107-29.

Brückner, M. (2012) "Economic growth, size of the agricultural sector, and urbanization in Africa.” Journal of Urban Economics, 71, 26-36.

Brückner, M. (2013) “On the simultaneity problem in the aid and growth debate.” Journal of Applied Econometrics, 28, 126-150.

Burger, D. and Walters, S. (2003). “Market Size, Pay, and Performance.” Journal of Sport Economics, 4(2), 108-125.

Castellanos, P., Dopico, J. and Sánchez, J.M. (2007). "The Economic Geography of football success: empirical evidence from European Cities.” Rivista di Diritto et Economia dello Sport, 3(2), 67-88.

Castells-Quintana, D. (2016) "Malthus living in a slum: Urban concentration, infrastructure and economic growth. ” Journal of Urban Economics, 92, 31-47.

Dimitrov, C., C. Helmenstein, A. Kleissner, B. Moser, and J. Schindler. (2006). "Die Makroökonomischen Effekte des Sports in Europa." Studie im Auftrag des Bundeskanzlermats, Sektion Sport, März. Vienna: Sports Econ Austria.

Duranton, G. and Pugba, D. (2004). "Micro-Foundations of Urban Agglomeration Economies." Handbook of Urban and Regional Economics, Edition 1, Vol. 4: 2063-2117, J.V. Henderson and J.F. Thisse (eds.)

FIFA. (2014). "FIFA World Cup Brazil. Television Audience Report. Available at http://resources.fifa.com/mm/document/affederation/tv/02/74/55/57/2014fwcbraziltvaud iencereport(draft5)(issuedate14.12.15)_neutral.pdf

Fløtnes, T. (2011). "Factors of success for Norwegian top football clubs - And why profit making is difficult for European football clubs." Copenhagen Business School. M. Sc. Applied Economics and Finance.

Frick, B. (2009). “Globalization and factor mobility: the impact of the 'Bosman-Ruling' on player migration in professional soccer.” Journal of Sports Economics, 10, 88-106.

Gásquez, R. and Royuela, V. (2014). "Is football an indicator of development at the international level?” Social Indicator Research, 117(3), 827-848. 
Gásquez, R. and Royuela, V. (2016). "The Determinants of International Football Success: A Panel Data Analysis of the Elo Rating.” Social Science Quarterly, 97(2), 125141.

Gelade, G. A. and Dobson, P. (2007). "Predicting the comparative strengths of national football teams.” Social Science Quarterly, 88, 244-58.

Giulianotti, R. and Robertson R. (2004). "The globalization of football: a study in the glocalization of the 'serious life'.” The British Journal of Sociology, 55(4), 545-68.

Hoffman, R., Ging, L.C. and Ramasamy. B. (2002). “The socio-economic determinants of the international soccer performance.” Journal of Applied Economics, 5(2), 253-272.

Hoffman, R., Ging, L.C., Matheson, V. and Ramasamy. B. (2006). "International women’s football and gender inequality.” Applied Economic Letters, 13, 999-1001.

Houston, R.G. and Wilson, D. (2002). "Income, leisure and proficiency: an economic study of football performance.” Applied Economics Letters, 9, 939-943.

Jacobs, J. (2014). "Programme-level determinants of women's international football performance.” European Sport Management Quarterly, 14(5), 521-537.

Karaca, O. (2008). "The impact of foreign players on international football performance.” Munich Personal RePEc Archive, MPRA Paper No. 11064. Online at http://mpra.ub.unimuenchen.de/11064/

Kleven, H.J., Landais. C. and Saez, E. (2013). “Taxation and International Migration of Superstars: Evidence from the European Football Market.” American Economic Review, 103(5), 1892-1924.

Leeds, M.A. and Leeds, E.M. (2009). "International Soccer Success and National Institutions.” Journal of Sports Economics, 10(4), 369-390.

Macmillan, T. and Smith, I. (2007). “Explaining International Soccer Rankings.” Journal of Sports Economics, 8(2), 202-213.

Milanovic, B. (2005). “Globalization and goals: does soccer show the way?” Review of International Political Economy, 12(5), 829-850.

Osso and Szymansky (1991). "Who are the Champions? (An analysis of football and architecture).” Business Strategy Review Summer, 113-130.

Taylor, M. (2006). "Global Players? Football, Migration and Globalization, c. 19302000.” Historical Social Research, 31(1), 7-30.

Torgler B. (2004a). “The Economics of the FIFA Football Worldcup.” KYKLOS, 57(2), 287-300. 
Torgler B. (2004b). “The determinants of women's international soccer performances.” Center for Research in Economics, Managements and Arts, working paper no. 2004-19.

Torgler B. (2004c). "Historical Excellence in football world cup tournaments: empirical evidence with data from 1930 to 2002.” Center for Research in Economics, Managements and Arts, working paper no. 2004-18.

Troelsen, T. (2005). "Centralisering af dansk fodbold: En statistisk analyse med bud på årsagsforklaringer. Kommunal støtte til professionel fodbold.” I J. Magnussen, \& R. K. Storm (red.), Professionel fodbold. Klim, Århus, s. 69-86.

Szymanski, S. (2003). “The Economic Design of Sporting Contest.” Journal of Economic Literature, 41 (4), 1137-1187.

The Economist. (2014) "Everything to play for. Good managers matter, but not as much as money does.” Available at http://www.economist.com/news/britain/21601873-goodmanagers-matter-not-much-money-does-everything-play.

Walker, B. (1986). "The demand for professional league football and the success of football league teams: some city size effects.” Urban Studies, 23(3), 209-219.

Yamamura, E. (2009). "Technology transfer and convergence of performance: an economic study of FIFA football ranking.” Applied Economics Letters, 16, 261-6. 


\section{Appendices of the paper "On the influence of foreign players on the success of football clubs"}

\begin{tabular}{|c|c|c|c|c|}
\hline 1. Albania & 25. & Finland & 49. & Norway \\
\hline 2. Algeria & 26. & France & 50. & Peru \\
\hline 3. Argentina & 27. & Georgia & 51. & Poland \\
\hline 4. Australia & 28. & Germany & 52. & Portugal \\
\hline 5. Austria & 29. & Ghana & 53. & Qatar \\
\hline 6. Azerbaijan & 30. & Greece & 54. & Qatar \\
\hline 7. Belarus & 31. & Hungary & 55. & Romania \\
\hline 8. Belgium & 32. & Iceland & 56. & Russia \\
\hline $\begin{array}{l}\text { Bosnia- } \\
\text { Herzegovina }\end{array}$ & 33. & India & 57. & Saudi Ara \\
\hline 10. Brazil & 34. & Iran & 58. & Scotland \\
\hline 11. Bulgaria & 35. & Israel & 59. & Serbia \\
\hline 12. Canada & 36. & Italy & 60. & Slovakia \\
\hline 13. Chile & 37. & Japan & 61. & Slovenia \\
\hline 14. China & 38. & Kazakhstan & 62. & South Africa \\
\hline 15. Colombia & 39. & Korea, South & 63. & Spain \\
\hline 16. Costa Rica & 40. & Lebanon & 64. & Sweden \\
\hline 17. Croatia & 41. & Luxembourg & 65. & Switzerland \\
\hline 18. Cyprus & 42. & Macedonia & 66. & Tunisia \\
\hline $\begin{array}{l}\text { 19. Czech } \\
\text { Republic }\end{array}$ & 43. & Mexico & 67. & Turkey \\
\hline 20. Denmark & 44. & Moldova & 68. & Ukraine \\
\hline 21. Ecuador & 45. & Montenegro & 69. & $\begin{array}{l}\text { United } \\
\text { States }\end{array}$ \\
\hline 22. Egypt & 46. & Morocco & 70. & Uruguay \\
\hline 23. England & 47. & Netherlands & 71. & Wales \\
\hline 24. Estonia & 48. & $\begin{array}{l}\text { New } \\
\text { Zealand }\end{array}$ & & \\
\hline
\end{tabular}




\section{Appendix 2. Variables: definition and sources}

\begin{tabular}{|c|c|c|}
\hline Variable & Description & Source \\
\hline Points & $\begin{array}{l}\text { Elo rating points of World Football Club } \\
\text { classification }\end{array}$ & http://footballdatabase.com/ \\
\hline Ranking & $\begin{array}{l}\text { Worls ranking based on Elo rating points of } \\
\text { World Football Club classification }\end{array}$ & http://footballdatabase.com/ \\
\hline Pop & Population of the city where every club is located & Wikipedia \\
\hline Market value & Market value of total players of the Team & http://www.transfermarkt.com/ \\
\hline Share Foreign players & Share of foreign players of each team (\%) & http://www.transfermarkt.com/ \\
\hline Age & Average age of players of each team & http://www.transfermarkt.com/ \\
\hline Weather Index & $\begin{array}{l}\text { (TEMP-14) squared, where TEMP refers the } \\
\text { weather of the city (in log) }\end{array}$ & http://www.weatherbase.com/ \\
\hline Foundation & Years of Foundation of the team & $\begin{array}{l}\text { www.soccerway.com } \\
\text { complemented with Wikipedia }\end{array}$ \\
\hline Capacity_Stadium & Capacity of the Stadium & $\begin{array}{l}\text { www.soccerway.com } \\
\text { complemented with Wikipedia }\end{array}$ \\
\hline CONCAFAF & $\begin{array}{l}\text { Confederation of North, Central American and } \\
\text { Caribbean Association Football }\end{array}$ & CONCAFAF \\
\hline CONMEBOL & South American Football Confederation & CONMEBOL \\
\hline AFC & Asian Football Confederation & AFC \\
\hline CAF & Confederation of African Football & CAF \\
\hline OFC & Oceania Football Confederation & OFC \\
\hline UEFA & European Union of Association Football & UEFA \\
\hline
\end{tabular}




\section{Appendix 3. Identification strategy}

As it is hard to find an instrument for the share of foreign players in every football team, we follow a two-step procedure following Brückner (2012, 2013) and Castells-Quintana (2016) to adjust for simultaneity bias. By using an instrument for the Elo ranking in 2010 we are able to build a valid instrument for the share of foreign players in our substantive estimation. The starting point is a simultaneous equation model where football success $\left(S_{i}\right)$ and the share of foreign football players $\left(M_{i}\right)$ are mutually related:

$$
\begin{aligned}
& S_{i}=\alpha\left(M_{i}\right)+u_{i} \\
& M_{i}=\theta\left(S_{i}\right)+e_{i}
\end{aligned}
$$

We are interested in estimating parameter $\alpha$, but if $\theta$ is not zero, OLS estimates in A1 will be biased and inconsistent. To overcome this problem we propose using instrumental variables for football migrants. If we can consistently estimate $\theta$ in A2, we can build an instrument to be used in A1 by capturing the residual: $\hat{e}_{t}=\operatorname{res}\left(M_{i}\right)=M_{i}-\hat{\theta} S_{i}$. Using this generated variable as instrument, the IV estimate of A1 will be free of simultaneity bias:

$$
\hat{\alpha}_{I V}=\frac{\operatorname{Cov}\left(\operatorname{res}\left(M_{i}\right), S_{i}\right)}{\operatorname{Cov}\left(\operatorname{res}\left(M_{i}\right), M_{i}\right)}=\alpha+\frac{\operatorname{Cov}\left(\operatorname{res}\left(M_{i}\right), u_{i}\right)}{\operatorname{Cov}\left(\operatorname{res}\left(M_{i}\right), M_{i}\right)}=\alpha+\frac{\operatorname{Cov}\left(e_{i}, u_{i}\right)}{\operatorname{Cov}\left(\operatorname{res}\left(M_{i}\right), M_{i}\right)}
$$

Still, as far as $\operatorname{COV}\left(e_{i}, u_{i}\right) \neq 0$ the omitted variable bias will exist. In order to avoid that bias, we include in our estimate country fixed effects in A2 together with the population size of every city.

In this strategy, timing is an important aspect. Thus, our first step consists on explaining the share of foreign football players as a function of past football success: we regress the share of foreign footballers in September 2015 against the Elo ranking dated in January 2010. We include then a set of country dummies $\left(I_{i}\right)$ that proxy national institutions, such as legal barriers.

$$
M_{i}^{2015}=\theta S_{i}^{2010}+\Theta I_{i}+e_{i}
$$

As an instrument for the Elo ranking in $2010\left(S_{i}^{2010}\right)$, we use information based on the history of every club. In particular we account for the year of foundation of the club and we compute its seniority $\left(\operatorname{Old}_{i}\right)$. With this variable we build the following set of instruments: the rank of seniority within every league (1), and its square (2), plus the rank of the ratio between the capacity of the stadium and the seniority of every team (3), and its square (4). Finally, we add the weather indicator differentiated by country. These instruments are expected to be correlated at some stage with the success of every team, but not to affect the share of foreign players. The first stage of equation A4 becomes:

$$
\begin{gathered}
S_{i}^{2010}=\rho_{1} \text { Rank_Old }_{i}+\rho_{2} \text { Rank }_{-} \text {Old }_{i}^{2}+\rho_{3} \text { Rank_Cap } / O l d_{i}+\rho_{4}{\text { Rank_Cap } / \text { Old }_{i}^{2}}^{2} \\
+\Xi \text { WeatherIndex } \\
+
\end{gathered}
$$

Table A7.1 displays the results of the first (A5) and second stage (A4) regressions. We find that our instruments are correlated with the classification of every team within its league (remember that we include league's dummies) and that in the second stage we find a non-significant Sargan statistic for over identification, what is a signal of the good performance of our instruments. Still, we have also performed additional checks for the exclusion restriction. First, we have computed the correlation between the residuals of equations A4 and A4, to check if $\operatorname{COV}\left(e_{i}, u_{i}\right)=0$. We obtain a correlation coefficient of -0.0378 , which is not significant even at $10 \%$ (p-val $=0.24$ ). Figure A7.1 displays the scatterplot between both residuals. Finally, figure A7.2 shows the scatterplots of the generated residuals of equation A4, which are correlated with the share of migrants but not with the Elo points. 
Table A7.1. Identification strategy

\begin{tabular}{|c|c|c|}
\hline & $\begin{array}{l}\text { ln Elo Points } \\
2010 \\
\text { OLS (1st stage) }\end{array}$ & $\begin{array}{l}\% \text { Foreign } \\
\text { Players } \\
\text { 2SLS }\end{array}$ \\
\hline Rank Old & $\begin{array}{c}-0.0044^{* * * *} \\
(0.001)\end{array}$ & \\
\hline Rank Old ${ }^{2}$ & $\begin{array}{c}0.000036 \\
(0.000061)\end{array}$ & \\
\hline Rank (Capacity/Old) & $\begin{array}{c}-0.0077 * * * \\
(0.001)\end{array}$ & \\
\hline Rank (Capacity/Old) ${ }^{2}$ & $\begin{array}{c}0.0001^{* *} \\
(0.000)\end{array}$ & \\
\hline ln Elo points 2010 & & $\begin{array}{c}0.4218 * * * \\
(0.112)\end{array}$ \\
\hline Interaction Weather -Index \# Country Dummies & YES & \\
\hline Country Dummies & YES & YES \\
\hline Observations & 968 & 968 \\
\hline R-squared & 0.587 & 0.712 \\
\hline $\begin{array}{l}\text { Anderson canon. corr. LM statistic for Underidentification } \\
\text { Sanderson-Windmeijer multivariate F test of excluded } \\
\text { instruments: }\end{array}$ & $\begin{array}{r}\text { Chi-sq(73) }=232 \\
F(73,825)=3.56\end{array}$ & P-val $=0.000$ \\
\hline Sargan Statistic test for Overidentification & Chi-sq(72) P & -val $=0.159$ \\
\hline
\end{tabular}

Figure A7.1. Scatter plots - generated residuals eq. A4 and A5

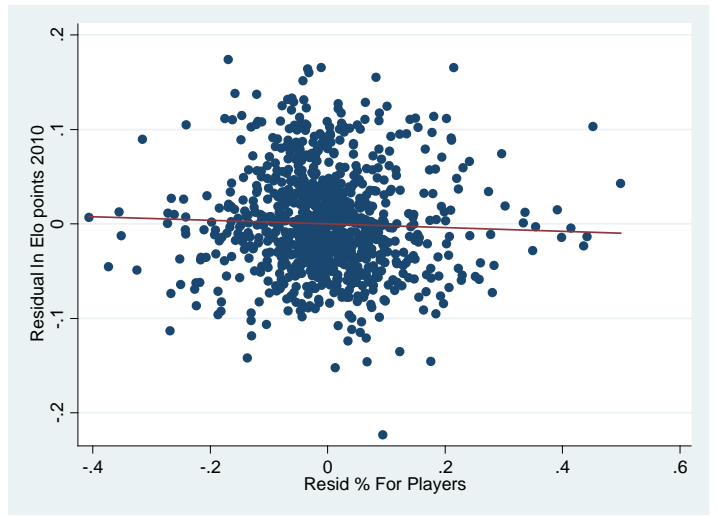

Figure A7.2. Scatter plots for the generated residuals

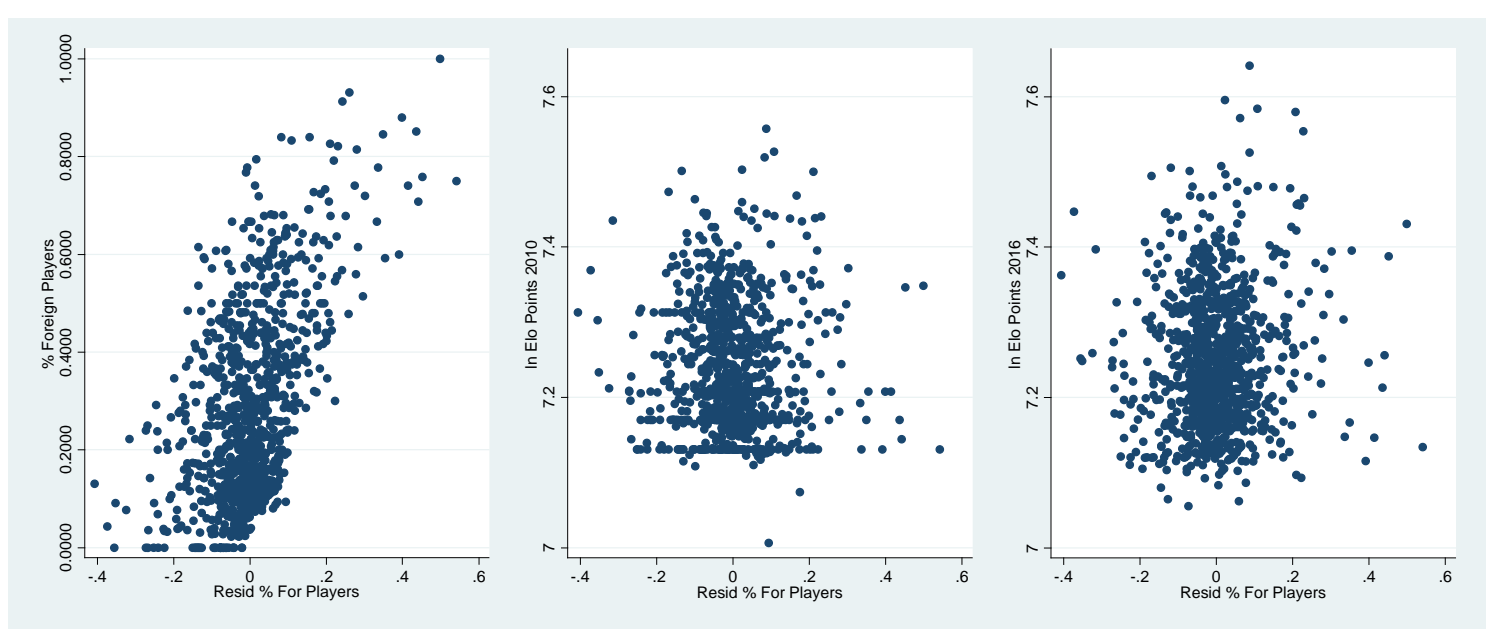




\section{Additional Materials of the paper "On the influence of foreign players on the success of football clubs"}

\section{Additional Material 1. Theoretical foundation of the empirical model, based on Bernard and Busse (2004)}

The production function of talent $\left(T_{i}\right)$ of the football teams in country $i$ requires a population $\left(N_{i}\right)$, economic resources $\left(Y_{i}\right)$, a warm temperature $\left(W_{i}\right)$, a number of football-related institutions $\left(I_{i}\right)$ and some organizational skills $\left(A_{i}\right)$ :

$$
T_{i}=f\left(N_{i}, Y_{i}, W_{i}, I_{i}, A_{i}\right)
$$

The relative football success, $S_{i}^{*}$, obtained by the country is a function of the talent in that particular country:

$$
E\left(\frac{\text { Football success }_{i}}{\sum_{j} \text { Football success }_{j}}\right)=S_{i}^{*}=g\left(T_{i}\right)
$$

A Cobb-Douglas talent production function is assumed:

$$
T_{i}=A_{i} N_{i}^{\gamma} Y_{i}^{\theta} W_{i}^{\varphi} I_{i}^{\xi}
$$

This characterization leads to the following specification for a country's relative success at football:

$$
\begin{gathered}
S_{i}^{*}=\ln \frac{T_{i}}{\sum_{j} T_{j}} \\
S_{i}=\ln A_{i}+\gamma \ln N_{i}+\theta \ln Y_{i}+\varphi \ln W_{i}+\xi \ln I_{i}-\ln \sum_{j} T_{j}
\end{gathered}
$$

As the socioeconomic variable, can be expressed as the product of population and per capita income, the specification to be estimated is:

$$
S_{i}=\beta_{0}+\beta_{1} \ln N_{i}+\beta_{2} \ln \left(\frac{Y}{N}\right)_{i}+\beta_{3} \ln W_{i}+\beta_{4} \ln I_{i}+u_{i}
$$

where $u_{i}$ the error term that is distributed normally. 


\section{Additional Material 2. The World Football Elo Rating System}

The World Football Elo Ratings are based on the Elo rating system, developed by Dr. Arpad Elo. This system is used by FIDE, the international chess federation, to rate chess players. In 1997 Bob Runyan adapted the Elo rating system to international football and posted the results on the Internet. He was also the first maintainer of the World Football Elo Ratings web site. The system was adapted to football by adding a weighting for the kind of match, an adjustment for the home team advantage, and an adjustment for goal difference in the match result.

These ratings take into account all international matches for which results could be found. Ratings tend to converge on a team's true strength relative to its competitors after about 30 matches. Ratings for teams with fewer than 30 matches should be considered provisional. Match data are primarily from International Football 1872 - Present.

The ratings are based on the following formulas:

$\mathbf{R}_{\mathbf{n}}=\mathbf{R}_{\mathbf{0}}+\mathbf{K} \times\left(\mathbf{W}-\mathbf{W}_{\mathbf{e}}\right)$

$\mathbf{R}_{\mathbf{n}}$ is the new rating; $\mathbf{R}_{\mathbf{0}}$ is the old (pre-match) rating.

$\mathbf{K}$ is the weight constant for the tournament played:

- $\quad 60$ for World Cup finals;

- $\quad \mathbf{5 0}$ for continental championship finals and major intercontinental tournaments;

- $\quad \mathbf{4 0}$ for World Cup and continental qualifiers and major tournaments;

- $\quad \mathbf{3 0}$ for all other tournaments;

- $\quad 20$ for friendly matches.

$\mathbf{K}$ is then adjusted for the goal difference in the game. It is increased by half if a game is won by two goals, by $\mathbf{3} / \mathbf{4}$ if a game is won by three goals, and by $\mathbf{3} / \mathbf{4}+(\mathrm{N}-3) / \mathbf{8}$ if the game is won by four or more goals, where $\mathbf{N}$ is the goal difference.

$\mathbf{W}$ is the result of the game ( $\mathbf{1}$ for a win, $\mathbf{0 . 5}$ for a draw, and $\mathbf{0}$ for a loss).

$\mathbf{W}_{\mathbf{e}}$ is the expected result (win expectancy), either from the chart or the following formula:

$\mathbf{W}_{\mathbf{e}}=1 /\left(10^{(-\mathbf{d r} / 400)}+1\right)$

dr equals the difference in ratings plus $\mathbf{1 0 0}$ points for a team playing at home. 
Sample Winning Expectancies

\begin{tabular}{|c|c|c|}
\hline Difference in rating & Higher related & Lower related \\
\hline 0 & 0.500 & 0.500000 \\
\hline 10 & 0.514 & 0.486 \\
\hline 20 & 0.529 & 0.471 \\
\hline 30 & 0.543 & 0.457 \\
\hline 40 & 0.557 & 0.443 \\
\hline 50 & 0.571 & 0.429 \\
\hline 60 & 0.585 & 0.415 \\
\hline 70 & 0.599 & 0.401 \\
\hline 80 & 0.613 & 0.387 \\
\hline 90 & 0.627 & 0.373 \\
\hline 100 & 0.640 & 0.360 \\
\hline 110 & 0.653 & 0.347 \\
\hline 120 & 0.666 & 0.334 \\
\hline 130 & 0.679 & 0.321 \\
\hline 140 & 0.691 & 0.309 \\
\hline 150 & 0.703 & 0.297 \\
\hline 160 & 0.715 & 0.285 \\
\hline 170 & 0.727 & 0.273 \\
\hline 180 & 0.738 & 0.262 \\
\hline 190 & 0.749 & 0.251 \\
\hline 200 & 0.760 & 0.240 \\
\hline 210 & 0.770 & 0.230 \\
\hline 220 & 0.780 & 0.220 \\
\hline 230 & 0.790 & 0.210 \\
\hline 240 & 0.799 & 0.201 \\
\hline 250 & 0.808 & 0.192 \\
\hline 260 & 0.817 & 0.183 \\
\hline 270 & 0.826 & 0.174 \\
\hline 280 & 0.834 & 0.166 \\
\hline 290 & 0.841 & 0.159 \\
\hline 300 & 0.849 & 0.151 \\
\hline 325 & 0.867 & 0.133 \\
\hline 350 & 0.882 & 0.118 \\
\hline 375 & 0.896 & 0.104 \\
\hline 400 & 0.909 & 0.091 \\
\hline 425 & 0.920 & 0.080 \\
\hline 450 & 0.930 & 0.070 \\
\hline 475 & 0.939 & 0.061 \\
\hline 500 & 0.947 & 0.053 \\
\hline 525 & 0.954 & 0.046 \\
\hline 550 & 0.960 & 0.040 \\
\hline 575 & 0.965 & 0.035 \\
\hline 600 & 0.969 & 0.031 \\
\hline 625 & 0.973 & 0.027 \\
\hline 650 & 0.977 & 0.023 \\
\hline 675 & 0.980 & 0.020 \\
\hline 700 & 0.983 & 0.017 \\
\hline 725 & 0.985 & 0.015 \\
\hline 750 & 0.987 & 0.013 \\
\hline 775 & 0.989 & 0.011 \\
\hline 800 & 0.990 & 0.010 \\
\hline
\end{tabular}




\section{Additional Material 3. Football Confederations}

a. The Asian Football Confederation (AFC) is the governing body of association football in Asia. It has 47 member countries, located in the main on the Asian continent. All the transcontinental countries with territory straddling both Europe and Asia are members of UEFA (Azerbaijan, Armenia, Georgia, Kazakhstan, Russia and Turkey). Israel, although it lies entirely in Asia, is also a UEFA member. Australia, formerly in the OFC, has been in the AFC since 2006, and the Oceanian island of Guam, a territory of the United States, is also a member of the AFC.

b. The Confederation of African Football (CAF) represents the national football associations of Africa.

c. The Confederation of North, Central American and Caribbean Association Football (CONCACAF) is the continental governing body for association football in North America, Central America and the Caribbean.

d. The South American Football Confederation (CONMEBOL) is the continental governing body for association football in South America.

e. The Oceania Football Confederation (OFC) is one of the six continental confederations of international association football, consisting of New Zealand and island nations such as Tonga, Fiji and other Pacific Island countries. In 2006, the OFC's largest and most successful nation, Australia, left to join the Asian Football Confederation.

f. The Union of European Football Associations (UEFA) is the administrative body for association football in Europe and, partially, Asia. UEFA membership coincides with sovereign countries in Europe, although some UEFA members are transcontinental states (e.g. Turkey). Several Asian countries have also been admitted to the European football association: Azerbaijan, Armenia, Georgia, Kazakhstan, Israel, Russia and Turkey, which had previously been members of the Asian football association. 


\section{Additional Material 4. Using market value as a proxy for budget}

\section{for salaries}

The top ten clubs with higher Market Value are displayed in table A5.1.

Table A5.1. World top ten clubs by Market Value (M €)

\begin{tabular}{|c|c|c|}
\hline League & Club & Market value \\
\hline Spain & Real Madrid & 704.8 \\
\hline Spain & FC Barcelona & 689.5 \\
\hline Germany & Bayern Munich & 578.55 \\
\hline England & Manchester City & 501.75 \\
\hline England & Chelsea FC & 490 \\
\hline England & Arsenal FC & 431 \\
\hline France & Paris Saint-Germain & 423.75 \\
\hline England & Manchester United & 411.25 \\
\hline Italy & Juventus FC & 379.8 \\
\hline England & Liverpool FC & 367.1 \\
\hline
\end{tabular}

In order to exemplify how Market Value is a good proxy of the Budget of the Club, we use data of the Spanish League, for which we record the Budget linked to the maximum amount that can be devoted to wages by every club, according to the rules dictated by the Professional Football League. Table A5.2 and Figure A5.1 report this data, and shows a strong correlation, close to $99 \%$.

Table A5.2. Market Value - Budget devoted to salaries. Spanish League 2015-06.

\begin{tabular}{|l|c|c|}
\hline \multicolumn{1}{|c|}{ Club(s) } & $\begin{array}{c}\text { Market } \\
\text { Value }\end{array}$ & Budget \\
\hline Athletic Bilbao & 134 & 53.6 \\
\hline Atlético Madrid & 325 & 159.6 \\
\hline Celta de Vigo & 75.7 & 22.6 \\
\hline Deportivo de La Coruña & 53.95 & 17.8 \\
\hline FC Barcelona & 689.5 & 421.7 \\
\hline Getafe CF & 51.1 & 20.7 \\
\hline Granada CF & 61.9 & 25.2 \\
\hline Levante UD & 58.75 & 25.9 \\
\hline Málaga CF & 57.9 & 28.7 \\
\hline Rayo Vallecano & 41.45 & 20.9 \\
\hline RCD Espanyol Barcelona & 60.6 & 30.6 \\
\hline Real Betis Balompié & 61 & 39.1 \\
\hline Real Madrid & 704.8 & 431.3 \\
\hline Real Sociedad & 115.4 & 56.6 \\
\hline SD Eibar & 40.8 & 19.11 \\
\hline Sevilla FC & 186.2 & 105.13 \\
\hline Sporting Gijón & 39.05 & 14.6 \\
\hline UD Las Palmas & 29.25 & 18.4 \\
\hline Valencia CF & 282 & 122.8 \\
\hline Villarreal CF & 135.8 & 61.5 \\
\hline
\end{tabular}

Figure A5.1. Scatter plot Market Value - Budget devoted to salaries

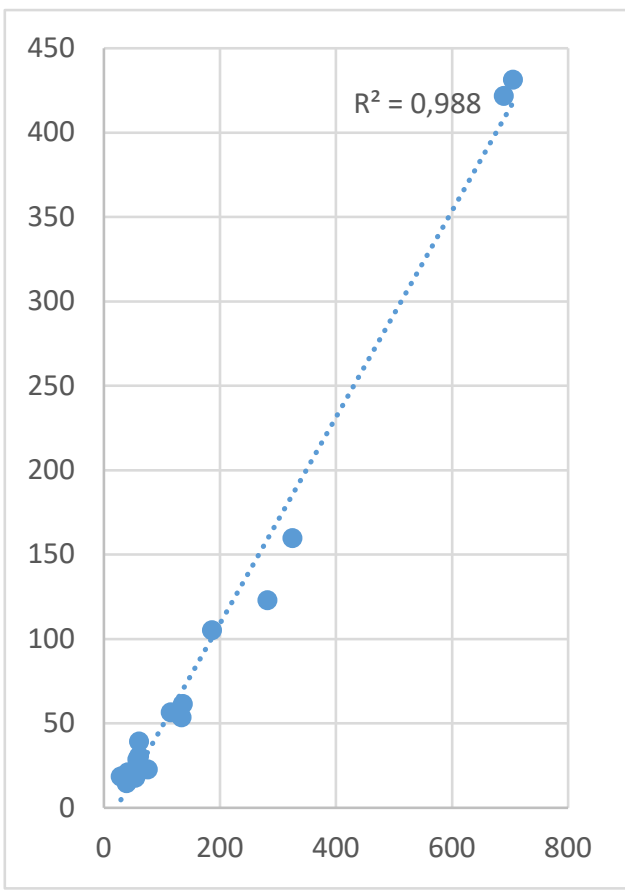




\section{Additional Material 5. Robustness checks. Negative binomial and log-log estimates}

Tabla A8.1. Negative binomial regressions of World Ranking

\begin{tabular}{|c|c|c|c|c|c|c|c|}
\hline & $\begin{array}{c}(1) \\
\text { World } \\
\text { Sample }\end{array}$ & $\begin{array}{c}(2) \\
\text { World } \\
\text { Sample }\end{array}$ & $\begin{array}{c}(3) \\
\text { World } \\
\text { Sample }\end{array}$ & $\begin{array}{c}(4) \\
\text { World } \\
\text { Sample }\end{array}$ & $\begin{array}{c}(5) \\
\text { UEFA }\end{array}$ & $\begin{array}{c}\text { (6) } \\
\text { CONMEBOL }\end{array}$ & CONC \\
\hline Share Foreign players & $\begin{array}{c}0.728 * * * \\
(0.225)\end{array}$ & $\begin{array}{l}-0.149 \\
(0.169)\end{array}$ & $\begin{array}{c}0.813 * * * \\
(0.210)\end{array}$ & $\begin{array}{c}0.198 \\
(0.152)\end{array}$ & $\begin{array}{c}0.261 \\
(0.168)\end{array}$ & $\begin{array}{c}0.302 \\
(1.232)\end{array}$ & $\begin{array}{l}-0.7 \\
(0.4\end{array}$ \\
\hline In Population & $\begin{array}{l}0.00926 \\
(0.0198)\end{array}$ & $\begin{array}{r}-0.00782 \\
(0.0126)\end{array}$ & $\begin{array}{c}0.0108 \\
(0.0179)\end{array}$ & $\begin{array}{r}-0.00381 \\
(0.0109)\end{array}$ & $\begin{array}{c}-0.0144 \\
(0.0133)\end{array}$ & $\begin{array}{c}-0.000909 \\
(0.0335)\end{array}$ & $\begin{array}{l}-0.0 \\
(0.06\end{array}$ \\
\hline Weather Index & $\begin{array}{c}-0.000299 \\
(0.000601)\end{array}$ & $\begin{array}{c}0.000772 \\
(0.000693)\end{array}$ & $\begin{array}{c}-0.000384 \\
(0.000634)\end{array}$ & $\begin{array}{c}0.000665 \\
(0.000630)\end{array}$ & $\begin{array}{c}0.000151 \\
(0.000831)\end{array}$ & $\begin{array}{c}0.000146 \\
(0.000980)\end{array}$ & $\begin{array}{r}0.00 \\
(0.00\end{array}$ \\
\hline ln Market value & $\begin{array}{c}-0.140 * * * \\
(0.0395)\end{array}$ & $\begin{array}{c}-0.493 * * * \\
(0.0545)\end{array}$ & $\begin{array}{c}-0.156 * * * \\
(0.0461)\end{array}$ & $\begin{array}{c}-0.520 * * * \\
(0.0406)\end{array}$ & $\begin{array}{c}-0.612 * * * \\
(0.0682)\end{array}$ & $\begin{array}{c}-0.868 * * \\
(0.409)\end{array}$ & \\
\hline ln Market value ${ }^{2}$ & $\begin{array}{l}-0.108^{* * *} \\
(0.00905)\end{array}$ & $\begin{array}{l}-0.105^{* * *} \\
(0.00908)\end{array}$ & $\begin{array}{l}-0.105 * * * \\
(0.00987)\end{array}$ & $\begin{array}{c}-0.103^{* * *} \\
(0.00662)\end{array}$ & $\begin{array}{c}-0.0989 * * * \\
(0.00886)\end{array}$ & $\begin{array}{c}0.0443 \\
(0.0742)\end{array}$ & \\
\hline In Capacity Stadium & $\begin{array}{c}-0.0962 * * \\
(0.0382)\end{array}$ & $\begin{array}{c}-0.0891^{* * *} \\
(0.0296)\end{array}$ & $\begin{array}{c}-0.0987 * * * \\
(0.0375)\end{array}$ & $\begin{array}{c}-0.0959 * * * \\
(0.0250)\end{array}$ & $\begin{array}{l}-0.0524 \\
(0.0363)\end{array}$ & $\begin{array}{c}-0.213^{* *} \\
(0.105)\end{array}$ & $\begin{array}{r}-0.13 \\
(0.0\end{array}$ \\
\hline SFP_res & & & $\begin{array}{c}54.24 * * * \\
(8.340)\end{array}$ & $\begin{array}{c}60.76 * * * \\
(7.463)\end{array}$ & $\begin{array}{c}52.26 * * * \\
(9.273)\end{array}$ & $\begin{array}{l}-3.413 \\
(26.76)\end{array}$ & \\
\hline Constant & $\begin{array}{c}8.037 * * * \\
(0.275)\end{array}$ & $\begin{array}{c}9.653^{* * *} \\
(0.266)\end{array}$ & $\begin{array}{c}8.106 * * * \\
(0.299)\end{array}$ & $\begin{array}{c}9.700 * * * \\
(0.224)\end{array}$ & $\begin{array}{c}9.568 * * * \\
(0.318)\end{array}$ & $\begin{array}{c}9.749 * * * \\
(0.998)\end{array}$ & $\begin{array}{r}11.3 \\
(2.7\end{array}$ \\
\hline Country Dummies & NO & YES & NO & YES & YES & YES & \\
\hline ln alpha & $\begin{array}{c}-1.107 * * * \\
(0.0815)\end{array}$ & $\begin{array}{c}-1.589 * * * \\
(0.0860)\end{array}$ & $\begin{array}{c}-1.181 * * * \\
(0.0856)\end{array}$ & $\begin{array}{c}-1.729 * * * \\
(0.101)\end{array}$ & $\begin{array}{c}-1.768 * * * \\
(0.123)\end{array}$ & $\begin{array}{c}-1.358 * * * \\
(0.139)\end{array}$ & $\begin{array}{r}-1.89 \\
(0.1\end{array}$ \\
\hline Observations & 970 & 970 & 968 & 968 & 571 & 129 & 5 \\
\hline
\end{tabular}

Note: Robust standard errors clustered by country in parentheses. ${ }^{* * *} \mathrm{p}<0.01$, ${ }^{* *} \mathrm{p}<0.05$, ${ }^{*} \mathrm{p}<0.1$. Models including as regressor SFP_res are controlling for endogeneity by means of the Control Function Approach, as we include the generated residual of an equation where the Share of Foreign Players depend on all control variables plus a list of excluding instruments, namely the generated instrument reported in appendix 7 plus the average age of players in every team.

Tabla A8.2. Elo points regressions. IV estimates.

\begin{tabular}{|c|c|c|c|c|c|c|}
\hline & $\begin{array}{c}(1) \\
\text { World } \\
\text { Sample } \\
\end{array}$ & UEFA & CONMEBOL & CONCACAF & CAF & AFC - OFC \\
\hline Share Foreign players & $\begin{array}{l}-18.0137 \\
(18.526)\end{array}$ & $\begin{array}{l}-18.5044 \\
(21.141)\end{array}$ & $\begin{array}{c}-0.8221 \\
(130.435)\end{array}$ & $\begin{array}{l}67.0160 \\
(84.807)\end{array}$ & $\begin{array}{c}31.4755 \\
(114.631)\end{array}$ & $\begin{array}{l}-90.2161 \\
(63.521)\end{array}$ \\
\hline In Population & $\begin{array}{l}1.3537 \\
(1.466)\end{array}$ & $\begin{array}{l}2.1962 \\
(1.837)\end{array}$ & $\begin{array}{l}1.4402 \\
(3.024)\end{array}$ & $\begin{array}{l}5.5291 \\
(7.157)\end{array}$ & $\begin{array}{l}-1.4372 \\
(3.179)\end{array}$ & $\begin{array}{l}2.5610 \\
(4.552)\end{array}$ \\
\hline Weather Index & $\begin{array}{l}-0.0268 \\
(0.086)\end{array}$ & $\begin{array}{l}0.0635 \\
(0.129)\end{array}$ & $\begin{array}{l}0.0533 \\
(0.149)\end{array}$ & $\begin{array}{c}-0.3807 * \\
(0.197)\end{array}$ & $\begin{array}{l}0.0550 \\
(0.225)\end{array}$ & $\begin{array}{l}-0.0342 \\
(0.181)\end{array}$ \\
\hline ln Market value & $\begin{array}{c}76.2571^{* * *} \\
(7.772)\end{array}$ & $\begin{array}{c}97.1647^{* * *} \\
(10.320)\end{array}$ & $\begin{array}{c}126.0772 * * * \\
(40.356)\end{array}$ & $\begin{array}{l}44.9985 \\
(97.329)\end{array}$ & $\begin{array}{c}74.1756 * * * \\
(7.622)\end{array}$ & $\begin{array}{l}-6.7516 \\
(18.640)\end{array}$ \\
\hline ln Market value ${ }^{2}$ & $\begin{array}{c}9.1983 * * * \\
(1.182)\end{array}$ & $\begin{array}{c}7.2045^{* * *} \\
(1.427)\end{array}$ & $\begin{array}{l}-9.6598 \\
(7.135)\end{array}$ & $\begin{array}{c}6.4672 \\
(18.929)\end{array}$ & $\begin{array}{c}19.3227 * * * \\
(1.765)\end{array}$ & $\begin{array}{c}40.0886 * * * \\
(6.347)\end{array}$ \\
\hline
\end{tabular}




\begin{tabular}{|c|c|c|c|c|c|c|}
\hline In Capacity Stadium & $\begin{array}{c}13.3003 * * * \\
(3.366)\end{array}$ & $\begin{array}{l}7.0710 \\
(4.429)\end{array}$ & $\begin{array}{c}27.9330 * * * \\
(9.311)\end{array}$ & $\begin{array}{l}24.2508 \\
(15.219)\end{array}$ & $\begin{array}{l}1.6509 \\
(5.385)\end{array}$ & $\begin{array}{l}12.5905 \\
(11.719)\end{array}$ \\
\hline Country Dummies & YES & YES & YES & YES & YES & YES \\
\hline KP statistic (p-val) & $\begin{array}{c}171.1 \\
(0.000)\end{array}$ & $\begin{array}{c}131.2 \\
(0.000)\end{array}$ & $36.56(0.000)$ & $9.800(0.020)$ & $\begin{array}{c}30.72 \\
(0.000)\end{array}$ & $\begin{array}{c}13.52 \\
(0.004)\end{array}$ \\
\hline J-Statistic (p-val) & $\begin{array}{c}2.524 \\
(0.283)\end{array}$ & $\begin{array}{c}6.454 \\
(0.039)\end{array}$ & $3.224(0.200)$ & $0.429(0.807)$ & $\begin{array}{c}2.669 \\
(0.263)\end{array}$ & $\begin{array}{c}1.638 \\
(0.441)\end{array}$ \\
\hline Observations & 970 & 571 & 129 & 50 & 95 & 125 \\
\hline R-squared & 0.818 & 0.867 & 0.632 & 0.597 & 0.713 & 0.689 \\
\hline
\end{tabular}

Note: Robust standard errors in parentheses. ${ }^{* * *} \mathrm{p}<0.01,{ }^{* *} \mathrm{p}<0.05,{ }^{*} \mathrm{p}<0.1$. All models use the generated residual resulting from the two-steps Brückner strategy together with the average Age (and its square) of players in every team. KP refers to the under-identification Kleibergen-Paap LM statistic, while the J statistic corresponds to the over-identification Hansen J-Statistic. 